\title{
Angoulême, 2010
}

The 2010 Festival International de la Bande Dessinée was a somewhat smaller celebration of the form than had been typical from recent years. The global economic recession hit the festival in a very direct fashion, with a great deal of public sabre-rattling in the press between the festival and the town over who would pay which bills. In the end that bickering was resolved and the show, under the presidency of Blutch, rolled out under the grey skies and wet snow of the final weekend of January.

The highlight of the show was apparent to everyone, even before arriving: the opportunity to visit the new comics museum on the banks of the Charente river. The 4000 square metre museum, which opened in June 2009 and was constructed at a cost nearing ten million Euros, is a significant architectural upgrade over the old CNBDI building (now rechristened the Castro building, and turned over to exhibitions featuring children's comics). Aside from meeting space, lecture halls, a library and an impeccably laid out bookstore, the new museum features a much larger area for temporary exhibitions, as well as a very thoughtfully constructed space for the permanent exhibition. The latter is organised around a series of curved benches backed by glass vitrines. Visitors can take in the displays featuring original art and examples of comic books that detail the history of the art form, and also sit and read copies of many of the works on display. To the side are smaller rooms for temporary displays of a limited size. During the festival, one of these was given over to the beautifully produced pages from Martin Vaughn-James' overlooked abstract comics masterpiece, The Cage.

The main temporary exhibition during the festival, Cent pour cent, was one of the most anticipated of the show, but also one of the most disappointing. One hundred cartoonists were invited to select a single page from the museum's holdings of original art and redraw it, either as a copy in their own style or as a commentary on the original work. With so many pieces on display, the ratio of excellent work to the merely passable was not high, although the museum should be congratulated on making use of its holdings in an innovative manner. A nice catalogue of this exhibition was produced by the museum for those interested in seeing the works after the fact.

Back up atop the hill, a number of exhibitions were more impressive. Traditionally, the president of the festival is the subject of a major retrospective, but Blutch refused to have his comics displayed in a museum setting, arguing that he believes those works to be composed solely for book publication. Instead, he mounted a show of new and old drawings, mostly in full colour and without words. The tone of this show was quite dark, as much of the work dealt with violently sexual themes, but the quality of the individual drawings was rather high. Accompanying this exhibition was another by comics surrealist Fabio Viscogliosi, whose illustrations were generally larger than those 
of Blutch, but often simpler and more austere. This exhibition also contained a pair of striking sculptures by the author.

Fabrice Neaud, who lives in Angoulême year round and has made the town the subject of much of his autobiographical output, was the subject of a very striking show in the Hôtel Saint-Simon. Combining his work in comics with photography and oil paintings, he displayed older works from his Journal series and Beaux Arts Magazine, and newer, unpublished pieces. In the Castro building a pair of OuBaPo artists Étienne Lécroart and Jochen Gerner - had twinned exhibitions. Each of these artists is pushing the boundaries of comics in interesting ways. In addition to traditionally drawn comics produced on white paper, Gerner displayed a series of paintings on old comics covers that he has reduced to semiotic essentials, and Lécroart provided comics made out of wood that can be physically manipulated (through the use of hinges, for example) to create works that are readable in multiple and often contradictory fashions.

One final innovative show was arranged by the Paris/Brussels-based publisher Frémok, who displayed the pages of their book, Match de catch à Vielsam, in which the artists Olivier Deprez, Vincent Fortemps, Dominique Goblet, Thierry van Hasselt and Gipi worked with mentally handicapped artists to create collaborative works. The theme of this exhibition was also collaborative, as Fortemps and Van Hasselt worked with festival visitors to create a new comic during the course of the festival, with images derived from the Pippi Longstocking films. By foregrounding the process of collaborative comics production within the space of their exhibition, Frémok radically altered the dynamics of the festival in very interesting ways, and produced one of the most compelling exhibitions of recent years.

The most significant change to the festival from recent years was, without a doubt, the diminished presence of manga. With retreating sales numbers of manga volumes in France, and a new manga-oriented show in Paris in February, there was a sense from many that the festival and manga might have agreed to part ways. While the Espace Franquin continued to play the role of manga-building, hosting an exhibition about the series One Piece, this was the least visible manga have been at FIBD for a half decade or more.

Generally, this was a very well received festival, while the consensus was that the lack of a single blockbuster show meant that it would not be remembered as an all-time great. Publishers that I spoke with reported softer than expected sales at the tents, although, as usual, the retail spaces were overwhelmingly crowded, particularly on the weekend. Many events, such as the lecture by Robert Crumb, were filled well beyond capacity and had turn-away crowds, indicating that the festival is in no danger of losing its central status as the premiere comics event in Europe. Financing issues are expected to plague the festival into 2011 as a new funding deal with the city and region is negotiated, although no-one seriously believes that the attention of the comics world will be anywhere but Angoulême, as Baru leads the festival into its 38th edition in 2011.

BART BEATY

University of Calgary 